\title{
The Antecedents of the Regulation of the Economic Competition Agreement in the First Part of the 20tb Century in Hungary
}

\begin{abstract}
The regulations of the economic competition agreement were introduced by the 20th Act of 1931 after the economic crisis attention to the cartel regulations in Europe in the interwar period. We can realize that the regulation of the unfair business completion has a long codification history which started in the period of the Dualism. Before the end of dualism the Hungary regulated some question related to the cartels special attention to the circulation of commodities. In my presentation, I aim to describe the Hungarian and European codification antecedents and steps (for example: the regulation of industry) of the first Hungarian Cartel Act. This codification process was very important in Hungarian economy and social life because the economic changes started processes in both the field of legal life and legal sciences, and as a result of this, a demand arose to legally codify any rules in connection to cartels. The foundations of these were found in private law, especially in the regulations of the commercial law, which could be further elaborated upon and lead to a development of the regulations on the annulment of contracts in connection to dishonourable business competition.
\end{abstract}

Keywords: cartel law, competition, economic crisis, draft of cartel law, codification of cartel law, Word War I

Słowa kluczowe: prawo konkurencji, konkurencja, kryzys ekonomiczny, projekt prawa konkurencji, kodyfikacja prawa konkurencji, I wojna światowa

In The Effect of the War on Private Law, Antal Almási (1917) states, "The length of the peaceful period prior to the world war and the lack of a written code perhaps make the bias which virtually left Hungarian private law unprotected against events understandable, if not actually forgivable." Thus, he begins an outline of the status of private law and the reasons for the changes made to it as well as the effect of the world war on the content and drafting of legislation pertinent to the area of private law. In his opinion,

${ }^{1}$ Supported by János Bolyai Research Scholarship (BO/00198/18/9). Almási, A háború hatása, 8. 
"economic problems and legal danger" ${ }^{2}$ cannot be separated from the war; legislators and law enforcement officials must work together to counter the problem.

Given an understanding of the contemporary conditions of private law codification, it becomes clear that the role of the courts grew significantly in this period, particularly as regards the creation of legal certainty and legal unity. This was likewise the case after the world war broke out. Indeed, the Curia of Hungary, the country's supreme court, often attempted to reflect on the legal problems caused by the war. Absent a code of private law, it was incumbent upon the courts to pass down decisions on cartel cases based on existing legislation. It should be noted, however, that if Act XXXVII of 1875 (the Act on trade) or Act XVII of 1884 (the Act on industry) failed to provide a sufficient legal foundation "or an adequate analogy, then the court established the legal practice on cartels by drawing on the ancient sources of law: justice and dignity." ${ }^{3}$ In addition to legal development on the part of the courts, the government also needed to deal with the forming of cartel law. After all, the courts' rulings had less of an impact on economic processes.

It can be concluded that World War I had an effect on private law, more specifically on its codification, which came about primarily through state intervention. Indeed, in peace time, the state avoided intervening in private law relations, with the exception of legal protection, but this situation changed with the outbreak of war. Intervention was necessary in serving the public interest, which was the aim of the state, particularly as regards price regulation. The war also had an impact on the fulfilment of contracts, and judicial practice wished to react to that as well. Indeed, "the world war brought problems to the surface in the area of private law, which legislation and jurisprudence had not as yet addressed ad professo."

The war formally ended for Hungary with the Treaty of Trianon on 4 June 1920, Article III of which is especially relevant from the perspective of this topic: "Hungary undertakes to adopt all the necessary legislative and administrative measures to protect goods, the produce or manufacture of any one of the Allied and Associated Powers from all forms of unfair competition in commercial transactions." ${ }^{5}$ It was therefore due to historical events that a process of codification was necessarily launched, which attempted to reflect on these altered socio-economic conditions and provide legal certainty for the future. Behind the legislation lay the fact that the world war represented a break in the economic development of the countries of Europe from a number of aspects, as a consequence of which "the economic influence of the state grew to an extent never experienced before. ${ }^{\circ}$ During the period of serious economic crisis following World War I, Hungarian society demanded effective intervention with regard to price regulation.

In the aftermath of the war and as a consequence of the rising number of abuses tied to staple goods, the government took necessary measures as authorized by laws on exceptional measures in the case of war (Act LXIII of 1912 and Act L of 1914). ${ }^{7}$

${ }^{2}$ Ibid., 9.

3 Tunyogi Szűcs, "A karteltörvény", 53.

4 Schwartz, "A háború hatása", 124.

${ }^{5}$ Act XIII of 1921 (on the codification of the Treaty of Trianon, signed on 4 June 1920), Art. 210.

6 Pogány, "A nagy háború", 259-60; Kovács, "A kartellkérdés", 14-39.

${ }^{7}$ Kocsoh, "Az árellenőrzés jogszabályai", 342. Enacting this law had an impact on other areas of private law. Market regulation also affected the start of bankruptcy proceedings. Pétervári, "Csődeljárások", 85; Pétervári, 
Extraordinarily deep and wide-ranging changes were brought on in the economy by the events of World War I. A new legal solution had to be sought out to effectively regulate how staple goods were brought to market and consumed. The use and tightening of criminal sanctions represented the solution, in addition to the government introducing economic management measures. Act IX of 1916 contained criminal sanctions to protect the supply of goods to the public. ${ }^{8}$

It can be concluded that the war represented a shock from the perspective of production, as it caused economic uncertainty. In fact, the lack of goods after the war and the remnants of the wartime economy paved the way for speculation. Act XV of 1920 on price gouging endeavoured to regulate the situation through criminal law. ${ }^{9}$

The Act on usury was another attempt to use criminal law as a means to take action on price hikes; however, there was also a demonstrated need for business competition and the protection of competitive freedom.

Act V of 1923 on unfair competition was an attempt to fill the gap. The express aim of the law was to play a role in protecting business integrity, which represents the foundation of both economic life generally and business turnover specifically, an aim which was feasible through state intervention. This was necessary for the legislature to provide protection against unfair competition, since that could no longer be guaranteed based on the general rules of private law under the altered economic conditions. ${ }^{10}$

These efforts toward codification represent the antecedents that take us to the necessity of enacting a separate law in 1931 to regulate agreements to control business competition, a special and coordinated version of unfair market behaviour - the cartels.

\section{Draft bills submitted by the Council of Ministers}

On 5 April 1929, the Council of Ministers voted to have a bill drafted. ${ }^{11}$ It approved a request to the justice and trade ministers to "draft a bill on regulating the cartels and then put said bill before a meeting to be called in advance by the minister for trade." 12 The necessity of regulating the cartels likewise arose at the same session of the Council of Ministers, where the minister of justice was charged with drafting the Act on cartels and the minister for economics was tasked with gathering the codification material so that "the cartel question will be entirely clear to the legislative drafting department of the ministry of justice from an economic perspective." ${ }^{\prime 13}$

\footnotetext{
"A kivételes", 25-40.

${ }^{8}$ Wiener, "Gazdasági büntetőjogunk", 767.

9 Dobrovics, "Kartel”, 16; Homoki-Nagy, "Történetek", 38-42.

${ }^{10}$ Krusóczki, "A tisztességtelen verseny”, 249-51; Krusóczki, “A jóerkölcs magánjogi megítélése”, 75-86.

${ }^{11}$ Tunyogi Szücs, A karteltörvény elözményei, 54.

${ }^{12}$ Minisztertanácsi jegyzőkönyv 1925. szeptember 5. 12. pont.

${ }^{13}$ Minisztertanácsi jegyzőkönyv.1929. április 05. 3. sz. [Minutes of the Council of Ministers, 5 April 1929, No. 3]. No certified minutes for sessions of the Council of Ministers have survived for 13 November or 11 December 1930 or 16 January 1931, only a memorandum, from which it becomes clear that regulating the cartels was on the agenda.
} 


\section{The position of the Hungarian Jurists' Association on cartels}

A significant technical debate preceded the passing of the Act on cartels. Sometime minister of finance Baron Frigyes Korányi described a session of the Institute for Economic Law of the Hungarian Jurists' Association held in May 1929 as follows:

In this post-war confusion, if we wish to dismantle the web of causes and effects with sober minds and complete clarity and to recognise the true implications of individual functions of the economy or individual business combinations, the necessity and proper extent of regulation, and the true advantages and dangers of legislative or governmental intrusion, this can only be done with opinions from active participants and the most outstanding practical experts. ${ }^{14}$

But what is the cartel question? Is it an economic problem, a legal problem or both? We will understand the necessity of regulation if we find the answers to these questions.

According to contemporary legal and economic scholar Ödön Kuncz, cartels are primarily a matter of economic policy and the law must select the most appropriate tools to meet economic policy goals only. He expressed his position as follows: "We can set no other task for ourselves but to take this hopeful babe born of the inexhaustible imagination of economic life and experiencing its childhood here among us and bring it within the ramparts of the constitution as smoothly as possible." ${ }^{15}$ Kuncz believed that the problem could not be dealt with, i.e. the Act on cartels could not be drafted, by simply transplanting German, Norwegian or Canadian law, or, indeed, the U.S. Sherman AntiTrust Act, into the Hungarian legal system.

Free competition had experienced significant restrictions, as a consequence of which it was the task of the state to do everything to protect the public interest and to act effectively in the interests of freedom of contract and competition. During the codification process, it first had to be decided what the position of the legislator was with respect to regulating the cartels. The cartels could be viewed as arrangements that hinder the consolidation and development of the economy, thus leading to the Hungarian regulations following in the footsteps of the Canadian or U.S. anti-cartel trend and of the old Hungarian judicial practice of putting a halt to the development of cartels. In contrast, in the case of the bill, there was the option of accepting the position that the cartel is a legal tool which is necessary and even indispensable in the contemporary economic situation to maintain prices at an appropriate level.

The question arose whether this new economic and legal phenomenon should be granted a legal form. There was also the matter of whether the Hungarian cartel problem should be regulated in a law, whether a single law was necessary, or whether it was sufficient to leave solving the problem to judicial practice based on the laws in force (e.g. Act V of 1920 on usury and Act V of 1923 on unfair competition), general private law and the rules of trade law. This duty of the courts is also referred to in the draft Code of Private Law, Sec. 6, when it states that "on legal questions not regulated by law, the courts shall decide, taking into account the spirit of domestic law, general principles of law and conclusions drawn by legal scholars." 16

${ }_{14}$ A kartel, A magyar Jogászegylet Gazdaságjogi Intézetének, 4.

${ }_{15}$ Ibid., 19.

16 Ibid., 33.

Artykuły - Articles 
In addition, the form within which to legally regulate cartels needs to be found as well, as "they lay their eggs in others' nests like a cuckoo bird" ${ }^{17}$ This nest is none other than private law, more specifically trade law. However, Hungarian trade law failed to provide an appropriate legal foundation in this regard. ${ }^{18}$

The other issue awaiting a solution was what means the administrative authority or the court would endeavour to use "to provide protection against the cartel, with all its warts - or, if you like, with all its childhood diseases." ${ }^{19}$

In this respect, the decisions taken by the court of arbitration and jury for the Budapest Chamber of Commerce and Industry promoted the codification of the Act on cartels. For example, ruling No. 1925/1738 stated that a cartel in and of itself is not unfair if there is no intention to prevent free competition. In another ruling (No. 1927/4235), the court stated that it is not permitted to wipe out a competitor in open business competition. ${ }^{20}$

Another issue also arose during the debate, that of the proper extent of state intervention in private law to effectively protect consumers against the price dictatorship that develops out of the monopolistic situation of the cartels. Before the Act on cartels was passed, courts attempted to provide protection for consumers by annulling any cartel agreement associated with the occurrence of behaviour contrary to good morals. ${ }^{21}$ This was reflected in the draft Act on cartels as well, in the provision on a system of what were called cartel supervisory agencies.

\section{Antecedents to cartel law in contemporary laws}

As regards the codification of cartel law, mention must be made of laws that contained provisions which can be seen as antecedents to cartel regulation. One example is the Act on infractions of 1879, of which Sec. 128 banned collusion at a public auction among offences against property. ${ }^{22}$ Károly Dobrovics noted the regulation of cartels can rather be found in the Act on industry of 1884, Sec. 162, which protected both workers from being forced to accept unfavourable working conditions and wages due to collusion among industrialists and industrialists from a cessation of work, wage development and strikes among blue- and white-collar workers. ${ }^{23}$ The Act on Industry, Sec. 53, however, contains

17 Ibid.

18 Ibid., 24.

19 Ibid.

20 Ibid., 28.

21 Ibid., 30.

${ }^{22}$ Act XL of 1879, Sec. 128. "Any person who acts to invalidate or reduce the outcome of a public auction by collusion, by sharing the profits or through the promise of some other reward or advantage and any person who accepts part of the profits, reward or advantage for said purpose shall be imprisoned for a period of no more than two months and made to pay a fine of no more than three hundred forints." This section is cited in the rationale for the bill on agreements to control business competition (Rationale for the bill) in $\mathrm{Az}$ 1927. évi január hó 25-ére összehívott országgyülés nyomtatványai, 231.

${ }^{23}$ Act XVII of 1884, Sec. 162. "Collusion, through which industrialists aim to disrupt their business or, by dismissing blue- or white-collar workers, to set more burdensome working conditions for them, particularly to lower their wages; or through which blue- or white-collar workers force employers to pay them higher wages and generally to elicit better working conditions from said employers through a joint 
clear price regulation on beef. ${ }^{24}$ Nevertheless, these rules were not comprehensive regulations of cartel law; they were merely disparate, unsystematic bits of the law. ${ }^{25}$

Special mention must also be made of Hungarian trade law as an antecedent of cartel regulation. Indeed, this is the area of law where regulation of cartel law was able to evolve and take root in Hungarian private law. Act XXXVII of 1875, Sec. 179, stated what the general meeting of a public limited company could vote on: "entry into cartel agreements aimed at mutual profit in every company transaction". It is certainly clear that the aim of the trade law was not to regulate organisations deemed to have formed alliances in the sense of 20th-century cartel law.

The minutes of the meeting to discuss the draft trade law recall perfectly how preventing the circumvention of the ban on issuing new shares hung before lawmakers; specifically, the case of share capital not being entirely paid up when forming a new public limited company, with shares mutually exchanged and thus assets mutually transferred, cannot be ignored by the law. ${ }^{26}$

Even after the cartel law was passed, this provision of the trade law remained in force, meaning that it was possible for a profit-making cartel to be formed, in which public limited companies took part; thus, this provision had to be applied if necessary. ${ }^{27}$

\section{Bills and drafts tied to the codification of cartel law}

In 1900, minister for trade Sándor Hegedüs charged Zoltán Ráth, a lecturer at the Academy of Law in Kassa/Košice (in present-day Slovakia), to conduct a study on regulating the cartels with the aim of promoting future codification. The first section of the study covered the theoretical and historical foundation of the topic. It attempted to define the concept of the cartel and highlighted that a cartel is essentially a kind of agreement aimed at "reducing competition or completely shutting it out". ${ }^{28}$ The study also notes that after the Compromise of 1867 established the dual monarchy of Austria-Hungary, economic conditions changed significantly due to the customs union between the two

cessation of work; and all agreements aimed at supporting those who continue to support said collusion or to harm those who break with said collusion or which have no legal validity." Dobrovics, "Kartel", 14. Rationale for the bill, 231.

${ }^{24}$ Act XVII of 1884, Sec. 53. "In the event that individual communities enjoy the free exercise of meat fabrication and the beef supply to said communities cannot be constantly ensured, the industrial authority of second instance shall be entitled at the request of said communities to meet said request or to take special measures on a case by case basis while upholding rights acquired in toto. Such measures shall be taken after hearing testimony from the industrial authority of first instance and the chamber of commerce and industry based on the following principles: (a) the free exercise of beef fabrication ceases and a number is assigned to this industry; (b) the price of beef is periodically regulated; (c) the proper handling of beef fabrication is inspected by the industrial authority. Any citizen of the relevant community may appeal the measures set down in items (a) and (b) to the industrial authority."

${ }_{25}$ Dobrovics, "Kartel", 15.

${ }^{26}$ Ibid., 15. Reference is made here to Általános indokolás. Melléklet az 507. sz. irományhoz [General rationale. Annex to Document No. 507], 231.

${ }^{27}$ Dobrovics, "Kartel”, 15. Homoki-Nagy, „Megjegyzések”, 41.

${ }^{28}$ Stipta, István. "A gazdasági”, 54. 
countries. Any Hungarian cartel would have had close ties to a similar Austrian cartel. Finally, the author defined the responsibility of the Hungarian legislature, in particular with regard to the state's role in registering and monitoring the cartels. In addition to regulation by public law, it also covered problems associated with private law as well. ${ }^{29}$

The next step in regulating cartel law at the turn of the century was for Member of Parliament Pál Mandel to draft a bill, to which the rationale for the later cartel law also refers. If we follow the actual text of the bill, Mandel devoted space to the guidelines for regulation and a general introduction to cartels. ${ }^{30}$ The principles of the bill were as follows: freedom to enter into contracts, government monitoring, compensation, and the application of principles of private law and rules in cartel law. ${ }^{31}$ According to Mandel, "the draft proceeds from the position that one of the indispensable elements of the very development of our industry is the enacting of the cartel law." ${ }^{32}$

\section{The parliamentary debate on the cartel law}

The ministerial rationale for what was called the cartel law, or the Act on agreements to control business competition, highlighted that it is necessary to enact the law because "changes in living conditions, the development of techniques of production and transport in particular in the economy, and changes in rates of consumption make it necessary to transform the relationship between freedom and organisation based on the changed circumstances. ${ }^{\prime 33}$ The general rationale also made mention of the fact that civil equality and freedom of industry and trade had come about in the 19th century. Trends in economic theory came into focus that saw free competition as the foundation of public welfare. In passing the draft law, evaluating cartel agreements was significantly determined by the contemporary recognition that cartels could also have positive effects on the economy. Overproduction in the late 19th century resulted in significant price drops in certain areas of the economy, which led to companies posting losses and the economic crisis drastically reducing demand for goods, which was closely tied to changes in the labour market. "With such enormous shifts in external circumstances, the state could not spare even one organising social force and needed to accept compacts among business operators, which promoted more balanced development in the economy." 34 The most important aim in enacting the law was to put a halt to loopholes and legal uncertainty in cartel law.

The rationale referred to World War I and the subsequent changes in international relations, which had an effect on the Hungarian economy as well. Economic uncertainty made price speculation possible, which was a form of exploitation among the cartels.

${ }^{29}$ Ibid., 55.

${ }^{30} \mathrm{Ibid} ., 56$.

31 Mandel, "A kartell-törvényjavaslat", 321.

${ }^{32}$ Mandel, "A kartell-törvény tervezetéhez", 378.

33 Általános indokolás. Melléklet az 507. sz. irományhoz [General rationale. Annex to Document No. 507], 229. for an introduction to the dogmatic foundations of the codification, see Stipta, "Az elsö magyar kartelltörvény", 115-31.

${ }^{34}$ Rationale for the bill, 370. 
The bill on agreements to control business competition was submitted to Parliament on 23 January 1931 by parliamentary clerk Károly Csák, after it had been discussed by the justice, economics and transport committees. ${ }^{35}$ Debate began on the next sitting day, where the clerk introduced in detail why it was necessary to regulate cartelization.

In his opinion, the cartel question was primarily an economic problem. Economic principles needed to be established, after which the lawyer's task was to set up a system of legal instruments and norms. This:

[...] bill - in the press and in general - is called the cartel bill. That name actually fails to cover the content of the bill or its objective. The official title covers them much better because the bill does not wish to resolve the cartel question. It cannot. Naturally, however, it must deal with the entire cartel trend, every aspect of the economy, as it were, as a first issue. ${ }^{36}$

The clerk was implying that the regulation of private cartel law was overshadowed by public cartel law. The bill resulted in significant intervention in the economy. Old economic theories were swept aside, or they were engaged in a life-and-death struggle with new trends, as a result of which problems called for the economic philosophy side of the explanation. After the war, the oppressive effect of the cartels on the economy intensified. The antecedents of this effect stretch back to a period of capitalism in which free competition was able to function without restrictions. Indeed,

[...] their seeds are concealed in the anatomy of capitalism, in the capitalist system of production; the conditions they require to thrive are the same. While capitalism has developed under the protection of free competition and under the aegis of technological progress, the large plants and the concentration of capital have brought about a murderous competition worldwide, the natural consequence of which had to be a tendency to endeavour to pre-empt the risk for capital invested in companies and for workers' operating capital or at least to narrow that risk and thus organise production and establish structures which we know as cartels and arrangements with similar aims. ${ }^{37}$

Csák rightly drew the conclusion from the almost self-contradictory fact cited here that the trend toward cartels is a consequence of the complete and unrestricted manifestation of free competition. The principle of national economics states that free competition is the only guarantee of the economy, whose goal is to serve the public good. It was this very unrestricted and "murderous" competition that destroyed this principle, as free competition caused overproduction, which resulted in production anarchy. Following the war, both the state and companies through forced partnerships endeavoured to ensure continued production, one potential form of which was the cartel. Indeed, "cartels are necessary, unavoidable formations in the economy that cannot be ignored and cannot be erased." ${ }^{38}$ The clerk reinforced this by saying that the International Law Association and the Salzburger Juristentag took this position as well. ${ }^{39}$ One could not view cartels as being contrary to good morals simply on the basis of general principles of private law or view every cartel agreement as invalid. That was strengthened by the Curia of Hungary,

${ }_{35}$ Az 1927. évi január hó 25-ére hirdetett országgyülés, 22.

${ }^{36}$ Speech by parliamentary clerk Károly Csák. Ibid., 44.

${ }^{37}$ Ibid., 45.

${ }^{38}$ Ibid., 46.

${ }^{39}$ On international antecedents to regulation in this area, see Szilágyi, Tóth, "A kartellszabályozás történeti fejlődése", 9-10. 
the country's supreme court, in a 1911 decision, in which it declared that entering into a cartel agreement is not in and of itself contrary to good morals. ${ }^{40}$ The bill was based on the principle of freedom to form cartels, meaning that cartel agreements could not be viewed as being contrary to good morals a priori. If we accept that, then we arrive at the question of how the state should relate to cartels. The freedom to form cartels was based on the assumption that the state only needs to intervene in this matter if justified by the public interest and the economy. However, not everyone and not every country supported the formation of cartels. On the contrary, they wished to ban such business arrangements. In Csák's opinion, in addition to theory, one must examine the homo economicus, human nature. Indeed, Europe has also seen the development of

[...] a type whose most immediate life goal and whose life's greatest merit is making money, as they say in the United States, and this relentless money maker has no interest in the greater economy, nor does he see a common aim. His entire mentality and mental life is set up to see one merit before him: the acquisition of wealth. ${ }^{41}$

Nor did the clerk make a secret of the fact that there were Members of Parliament who did not at all support the move to make regulating cartels into law because it stood in the way of the continuity and certainty of production, provided higher pay for workers and prevented the concentration of capital. After the devastating economic effects of the Treaty of Trianon, it became particularly important to promote industry. The

$[\ldots]$ old classical school of economics taught that the legitimacy of the economy puts a halt to all overextension because when some establishment or some grouping abuses economic power, competition bears fruit in that moment, outsiders come, and the one that has abused economic power is regulated. ${ }^{42}$

Hungary's situation was completely different than that of other European countries. One could not simply adopt the German cartel decree, for example. Instead, the provisions of the bill had to be formed with the Hungarian conditions in mind, to which

[...] we have to add a plus sign and then insert the phrase "Treaty of Trianon". It is in this unfortunate situation created by the treaty that we are economically free. However, this freedom is so restricted and so overwhelmed that, in terms of economics in particular, this freedom "is worth less than that which we have lost". ${ }^{43}$

It had to be decided what is permitted and what it is that qualifies as forbidden in cartel law, meaning no less than establishing supervision and inspection of cartels. In that regard, it was an especially important question whether the emphasis in the bill should be on prevention or judicial proceedings. The Hungarian bill supported prevention and focused on government measures first and foremost, but it still established a Cartel Court in the event that administrative measures were not successful. One consequence of this was that the bill primarily regulated public cartel law, criminal law and pertinent procedural law. As regards the Cartel Court, the bill only recognised the actio publica. The bill was drafted

\footnotetext{
${ }^{40}$ Az 1927. évi január hó 25-ére hirdetett országgyülés, 46.

41 Ibid.

42 Ibid., 49.

43 Ibid., 50.
} 
in a period in which society was characterised by an anti-cartel mood. "After all, the trend toward cartels finds satisfaction in price policy, in price dictatorship and in the creation of monopolistic situations. It thus works in opposition to someone. This price policy is very natural: what profits one person harms another." ${ }^{\prime 4}$ The clerk remarked that this situation intensified after the war. The bill raised social issues as well, not only economic ones. "This era is marked by only agonizing economic problems. There is no point in complaining that ideals have become blurred. A great many ideas which guided and inspired us when we were young are now dying or have turned into shadows amidst the bitter problems of everyday life." ${ }^{45}$ Society did not expect theoretical, dogmatic solutions from lawmakers. It expected legal provisions that had an effect on people's lives, "or, to put it in plain language, will prices go down or not?"46

Hungarian barrister, author and Member of Parliament Marcell Baracs also highlighted the necessity of state intervention because he felt that while Act XV of 1921, Sec. 1 (4), defined collusion in relation to price gouging as a criminal activity sui generis, it did not achieve its goal entirely: it did not regulate the operation of the cartels. He felt that intervention was necessary to implement effective consumer protection due to the effect of price gouging on the state budget as well because high cartel prices had a depressing effect on the economy. Baracs judged a system of protective duties as a basically correct and acceptable solution, but he added that it created an opportunity to achieve gains beyond a fair profit, which meant nothing more in practice than high prices. He felt the consequences of cartelization in particular in the agricultural sector. "The friendly ties between the government and big business, i.e. between big industry and the cartels, have long remained in place undisturbed and would have continued to stay in place if the agricultural scissors had not emerged and threatened to snip those ties." ${ }^{.77}$ The introduction of government measures especially occupied this Member of Parliament, and he saw the guarantee of their success in ministerial responsibility. However, he saw no assurance of that due to the contemporary composition of Parliament. ${ }^{48}$

In his comments, ministerial councillor and Member of Parliament Elemér Farkas highlighted that

[...] cartels are justified if their aim is protective and if they do not cross the boundaries of legitimate protection with their actions. In my view, the appearance of cartels is suggested by a protective and self-preserving instinct in industry. True, if I take this very clear and simple position, then the other truth also emerges that the consumer's plight will never coerce industry. ${ }^{49}$

In his opinion, courts were of outstanding importance in this situation. He made reference to the draft Code of Private Law, Sec. 6, which stated that "on legal questions not regulated by law, the courts shall decide, taking into account the spirit of domestic law, general principles of law and conclusions drawn by legal scholars." ${ }^{50}$ This provision established a possibility of protection against "cartel outgrowths". In his

\footnotetext{
${ }^{44} \mathrm{Ibid}$., 54. On the establishment and operation of the cartel court, see Szabó, "A kartellfelügyelet", 64-84.

${ }^{45} \mathrm{Az}$ 1927. évi január hó 25-ére hirdetett országgyülés, 55.

${ }^{46}$ Ibid.

${ }^{47}$ Comments by Marcell Baracs. Ibid., 65 .

48 Ibid., 69.

${ }^{49}$ Comments by Elemér Farkas. Ibid., 71.

${ }^{50}$ Ibid.
} 
view, the codification of cartel law cannot be the goal of a criminal law "expedition"; appropriate means should have been found within the framework of civil law regulation. In the bill, the protection of public order and public morals was the primary element that even the Member supported because "it is actually the only aspect which, if we fail to take it into consideration, then there are no morals, no legal scholarship and no economic progress." ${ }^{11}$

Sándor Popper put forward a separate bill, which the committee debating the cartel bill rejected. In the bill, the MP stressed that a cartel is

$[\ldots]$ an agreement or decision that creates, maintains or changes the production, placing on the market and price development of goods, interest and credit conditions, wages to be paid to workers or employees, other working conditions or other facts restricting or regulating business competition. ${ }^{52}$

As regards the bill, he emphasised that such agreements should be written and public. According to Popper, the bill being debated did not protect the worker, the consumer or the cartel member and failed to address the insurance and bank cartels.

He concluded that monopoly capitalism was waging battle against the consumer and the worker in areas where the cartel had grown strong. In his opinion, this type of capitalism, in contrast to competitive capitalism, created a disparity between income and livelihood. The cartels were able to do this because "[...] the state is the largest cartel. [...] It is the government that is constantly making life more expensive." ${ }^{53}$ This is also why Roman Catholic priest and Member of Parliament Miklós Griger found it necessary to regulate the cartels' price gouging abuses. He agreed with Austrian economist Friedrich Kleinwächter's statement that the cartels are “[...] children of need, Kinder der Not [...], who were rocked in a golden cradle." ${ }^{54} \mathrm{He}$ also shared his opinion on the concentration of capital from a religious perspective, citing Roman Catholic bishop Ottokár Prohászka.

Since the bill was born in the spirit of the Gospel and social thinking that it is the duty of the state to protect the small from the big and the working masses from the exploitation of big business, since the realisation of this idea puts a weapon in the hands of the government, and, finally, since it is my right as a legislator to call the government to account in the matter of the use of weapons. ${ }^{55}$

Having summarised the facts, the Hungarian National Assembly emphasised that Act XX of 1931 had entered into force on 15 October $1931 .{ }^{56}$

${ }^{51}$ Ibid., 74.

${ }_{52}$ Comments and presentation by Sándor Popper. Ibid., 77.

${ }^{53}$ Ibid., 81-82.

${ }^{54}$ Comments by Miklós Griger. Ibid., 105.

${ }^{55}$ Ibid., 111.

${ }^{56}$ A kartelltörvény hatálybaléptetésről szóló 5381/1931. M. E. rendelet [Prime Minister Decree 5381 of 1931 on The Enforcement of the Cartel Act. P. IV.]. 


\section{Conclusion}

In summary, the state took extraordinarily strict action against abuses in business and against unfair competition. The war and the economic conditions that followed pushed individual interests into the background. What had been free before was banned after the war, as a consequence of which a series of laws were made (on price gouging, unfair competition and cartels), which intended to provide integrity in business and to protect consumers. The most important aim in codifying cartel law was to prevent abuses in economic power.

\section{Bibliography}

\section{Sources}

Minisztertanácsi jegyzőkönyv 1925. szeptember 5. 12. pont. [Minutes of the Council of Ministers, 5 September 1925, item 12]. http://adatbazisokonline.hu/adatbazis/minisztertanacsi-jegyzokonyvek-1867-1944 (access date: 30.08.2019).

Minisztertanácsi jegyzőkönyv 1929. április 05. 3. sz. [Minutes of the Council of Ministers, 5 April 1929, No. 3]. http://adatbazisokonline.hu/adatbazis/minisztertanacsi-jegyzokonyvek-1867-1944 (access date: 30.08.2019).

Az 1927. évi január hó 25-ére összehívott országgyülés nyomtatványai. Képviselöházi irományok, XXIII. k. [Printed matter for the session of Parliament called on 25 January 1927. Parliamentary documents (Vol. XXII)]. Budapest: Pesti Könyvnyomda Részvénytársaság, 1931.

Az 1927. évi január hó 25-ére hirdetett országgyülés képviselőházának naplója, 33. k. [Parliamentary Record for 25 January 1927 (Vol. 33)]. Budapest: Athenaeum Irodalmi és Nyomdai Részvénytársulat Könyvnyomdája, 1931.

\section{Secondary literature}

A kartel, A magyar Jogászegylet Gazdaságjogi Intézetének 1929. évi május hó 8-án, 14-én és 16-án tartott vitája [The cartel: Debate held by the Institute for Economic Law of the Hungarian Jurists' Association on 8, 14 and 16 May 1929]. Budapest: Magyar Jogászegylet, 1930.

Almási, Antal. A háború hatása a magánjogra [The effect of the war on private law]. Budapest: Magyar Jogászegylet, 1917.

Dobrovics, Károly. "Kartel. A karteljog fejlődése és a magyar törvény előzményei” [Cartel: The development of cartel law and antecedents to the Hungarian law]. Közgazdasági Értesitö 28 (1934): 16.

Homoki-Nagy, Mária. “Történetek a Szegedi Törvényszék müködéséröl” [Stories of the operation of the Court of Justice in Szeged]. In: A szegedi törvényszék története. IV. $k$. [History of the court in Szeged (Vol. IV)], eds Homoki-Nagy Mária, Pétervári Máté and Varga Norbert, 38-42. Szeged: Szegedi Törvényszék, 2019.

Homoki-Nagy, Mária. "Megjegyzések a kartellmagánjog történetéhez" [Remarks on the history of private cartel law]. Versenytükör Különszám II. 12 (2016): 41. 
Kocsoh, Bálint. “Az árellenőrzés jogszabályai” [The Laws of Price Monitoring]. Városi Szemle 25 (1939): 342.

Kovács, György. “A kartellkérdés és -szabályozás gazdaságelméleti és gazdaságpolitikai háttere a két világháború közötti magyar közgondolkodásban" [The economic theory and economic policy background to the cartel question and cartel regulation in the Hungarian public mind between the two world wars]. Versenytükör Különszám II 12 (2016): 14-39.

Krusóczki, Bence. “A jóerkölcs magánjogi megítélése a tisztességtelen verseny vonatkozásában" [The Private Law Judgement of Good Morals in Relation to Unfair Competition]. Jog, erkölcs, kultúra: Értékdillemmák és identitások a jogrendszerekben, eds Zs. Fejes et al., 75-86. Szeged: Szegedi Tudományegyetem, Állam- és Jogtudományi Kar, Doktori Iskola, 2020.

Krusóczki, Bence. “A tisztességtelen verseny a Szegedi Királyi Ítélőtábla joggyakorlatában" [Unfair competition in the legal practice of the Royal Regional Court of Appeal in Szeged]. Acta Universitatis Szegediensis, Forum, Publicationes Doctorandorum Juridicorum 1 (2018): 249-51.

Mandel, Pál. "A kartell-törvényjavaslat tervezete és a német jogászgyülés” [The draft cartel bill and the German Bar Association]. Jogtudományi Közlöny 32 (1904): 321.

Mandel, Pál. “A kartell-törvény tervezetéhez" [The draft cartel law]. Jogtudományi Közlöny 39 (1904): 378.

Pétervári, Máté. “A kivételes hatalomról rendelkező törvény alapján elrendelt moratóriumok hatása a csődeljárásokra" [The Effect of the Moratorium on Bankruptcy Proceedings in the Extraordinary Situation during the First World War]. Katonai Jogi és Hadijogi Szemle 2 (2020): 25-40.

Pétervári, Máté. “Csődeljárások a Szegedi Királyi törvényszék gyakorlatában”. In: A szegedi törvényszék története. IV. $k$. [History of the court in Szeged (Vol. IV)], eds Homoki-Nagy Mária, Pétervári Máté and Varga Norbert, 85. Szeged: Szegedi Törvényszék, 2019.

Pogány, Ágnes. "A nagy háború hosszú árnyéka: Az I. világháború gazdasági következményei” [The long shadow of the Great War: Economic consequences of World War I]. In: Az elsö világháború következményei Magyarországon [Consequences of World War I in Hungary], ed. Tomka Béla, 259-60. Budapest: Osiris, 2015.

Schwartz, Izidor. “A háború hatása a szerződések teljesítésére és az osztrák bírói gyakorlat" [The effect of the war on the fulfilment of contracts and Austrian judicial practice]. Jogtudományi Közlöny 51 (1916): 124.

Stipta, István. “Az első magyar kartelltörvény (1931. évi XX. tc.) dogmatikai jellemzői” [The dogmatic features of the first Hungarian cartel law (Act XX of 1931)]. FORVM Acta Juridica et Politica 5 (2015): 115-31.

Stipta, István. “A gazdasági versenyt szabályozó megállapodásokról szóló 1931. évi XX. tc. hazai előzményei” [The Antecedents of Act XX. of 1931 on Agreements regulating Economic Competition in Hungary]. Versenytükör Különszám II. 12 (2016): 54.

Szabó, István. "A kartellfelügyelet szervezete és hatásköre az 1931. XX. törvénycikk nyomán" [The organisation and jurisdiction of the cartel supervisory agency pursuant to Act XX of 1931]. Versenytükör Különszám II. 12 (2016): 64-84.

Szilágyi, Pál and Tóth, András. “A kartellszabályozás történeti fejlődése” [The historical development of cartel regulation]. Versenytükör Különszám II. 12 (2016): 9-10.

Tunyogi Szűcs, Kálmán. “A karteltörvény előzményei és alapelvei” [The cartel law: Antecedents and basic principles]. Karteljog Tára 1 (1931): 53.

Wiener, A. Imre. "Gazdasági büntetőjogunk történeti áttekintése" [Historical overview of Hungarian economic criminal law]. Jogtudományi Közlöny 37 (1982): 767. 